\title{
Multiple 'doughnut' granulomas in a liver transplant patient with CMV reactivation
}

\author{
Siroj Dejhansathit, ${ }^{1}$ Adam Michael Miller, ${ }^{2}$ Attaya Suvannasankha ${ }^{1}$
}

'Division of Hematology and Oncology, Department of Medicine, Indiana University School of Medicine, Indianapolis, Indiana, USA

${ }^{2}$ Pathology and Laboratory Medicine, Indiana University School of Medicine, Indianapolis, Indiana, USA

\section{Correspondence to} Dr Attaya Suvannasankha, asuvanna@iupui.edu

Accepted 15 November 2018

D Check for updates

(c) BMJ Publishing Group Limited 2018. No commercial re-use. See rights and permissions. Published by BMJ.

To cite: Dejhansathit $\mathrm{S}$, Miller AM, Suvannasankha A. BMJ Case Rep

2018;11:e227252.

doi:10.1136/bcr-2018

227252

\section{DESCRIPTION}

A 50-year-old man with a history of alcoholic cirrhosis and liver failure, postorthotopic liver transplantation 6 months prior, presented with failure to thrive and diffuse body pain for 1 month. Physical examination was unremarkable aside from low-grade fever. There was no adenopathy or rash.

A complete blood count showed leucopenia (white cell count: $1.4 \times 10^{9} / \mathrm{L}$ ), mild anaemia (haemoglobin: $124 \mathrm{~g} / \mathrm{L}$ ) and thrombocytopenia (platelets: $100 \times 10^{9} / \mathrm{L}$ ). Liver enzymes were normal. The bone marrow biopsy revealed normocellular marrow with adequate trilineage haematopoiesis and multiple 'doughnut' granulomas consisting of a central lipid vacuole surrounded by epithelioid histiocytes and a dense eosinophilic fibrin ring ${ }^{1}$ (figure 1A,B).

Gomori methenamine silver and acid-fast bacilli stains were negative. Serologic testing for fungi,
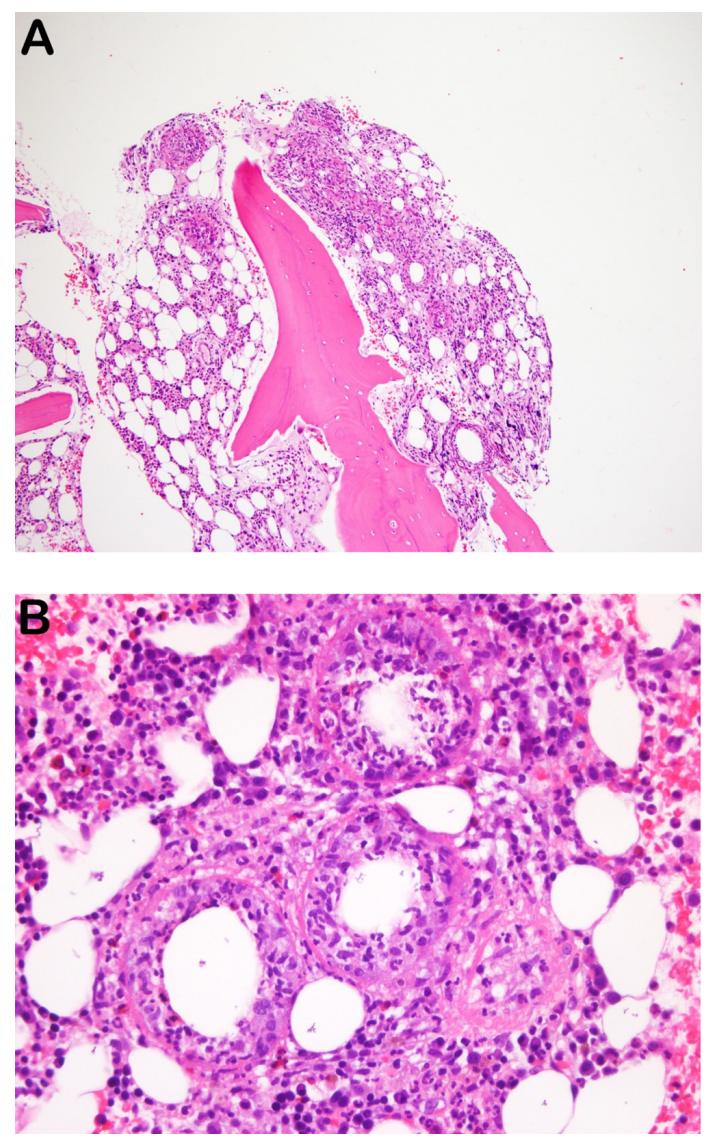

Figure 1 Bone marrow biopsy. H\&E staining showed a normocellular bone marrow with maturing trilineage haematopoiesis remarkable for multiple 'doughnut' granulomas consisting of a central lipid vacuole surrounded by fibrin and epithelioid histiocyte. (A) 100x, (B) 400x.
HIV, Treponema and Brucella was negative. Coxiella burnetii serology testing was negative. Quantitative PCR for cytomegalovirus (CMV) ${ }^{2}$ was below 500 copies $/ \mathrm{mL} 1$ month prior but had increased to 190000 copies/mL. Patient was diagnosed with CMV infection and treated with intravenous ganciclovir for 14 days, followed by oral valganciclovir ${ }^{3}$. Blood counts normalised 2 months after treatment, at which time CMV PCR was negative.

\section{Learning points}

- Fibrin ring or doughnut granulomas are a classical finding of Coxiella infection, but can also be attributed to other disseminated infections including Epstein-Barr virus, cytomegalovirus (CMV), hepatitis A virus, Leishmania donovani and Staphylococcus epidermidis, as well as non-infectious causes including allopurinol hypersensitivity and Hodgkin's disease.

- CMV infection is the most common viral infection in liver transplant recipients, caused by both a reactivation of CMV during the immunocompromised state and, less commonly, an acquired infection from seropositive organ donors or blood transfusion.

- Fever and pancytopenia are common presentation of CMV reactivation. Patient with severe or tissue-invasive syndromes should receive initial intravenous ganciclovir or foscarnet, which can be switched to oral regimen on clinical improvement. Mild disease in immunosuppressed patients may be treated with oral valganciclovir.

Contributors AS identified the important nature of this finding. SD reviewed literature, and drafted and edited the article. AS revised and approved the article. AMM is the pathologist concerned in this case. All authors have read and agreed with the content.

Funding The authors have not declared a specific grant for this research from any funding agency in the public, commercial or not-for-profit sectors.

Competing interests None declared.

Patient consent Obtained.

Provenance and peer review Not commissioned; externally peer reviewed.

\section{REFERENCES}

1 Young JF, Goulian M. Bone marrow fibrin ring granulomas and cytomegalovirus infection. Am J Clin Pathol 1993;99:65-8.

2 Razonable RR. Cytomegalovirus infection after liver transplantation: current concepts and challenges. World J Gastroenterol 2008; 14:4849-60.

3 Tan BH. Cytomegalovirus Treatment. Curr Treat Options Infect Dis 2014;6:256-70. 
Copyright 2018 BMJ Publishing Group. All rights reserved. For permission to reuse any of this content visit https://www.bmj.com/company/products-services/rights-and-licensing/permissions/

BMJ Case Report Fellows may re-use this article for personal use and teaching without any further permission.

Become a Fellow of BMJ Case Reports today and you can:

- Submit as many cases as you like

- Enjoy fast sympathetic peer review and rapid publication of accepted articles

Access all the published articles

- Re-use any of the published material for personal use and teaching without further permission

For information on Institutional Fellowships contact consortiasales@bmjgroup.com

Visit casereports.bmj.com for more articles like this and to become a Fellow 